\title{
New insights into the distributions of nitrogen fixation and diazotrophs revealed by high-resolution sensing and sampling methods
}

\author{
Weiyi Tang $\mathbb{1}^{1,5}$ - Elena Cerdán-García ${ }^{2}$ - Hugo Berthelot ${ }^{3}$ - Despo Polyviou ${ }^{2} \cdot$ Seaver Wang $\mathbb{D}^{1} \cdot$ Alison Baylay $^{2}$. \\ Hannah Whitby $\mathbb{1}^{3,6} \cdot$ Hélène Planquette ${ }^{3} \cdot$ Matthew Mowlem $^{4} \cdot$ Julie Robidart $\mathbb{C}^{4} \cdot$ Nicolas Cassar $\mathbb{D}^{1,3}$
}

Received: 18 August 2019 / Revised: 8 June 2020 / Accepted: 11 June 2020 / Published online: 24 June 2020

(c) The Author(s), under exclusive licence to International Society for Microbial Ecology 2020

\begin{abstract}
Nitrogen availability limits marine productivity across large ocean regions. Diazotrophs can supply new nitrogen to the marine environment via nitrogen $\left(\mathrm{N}_{2}\right)$ fixation, relieving nitrogen limitation. The distributions of diazotrophs and $\mathrm{N}_{2}$ fixation have been hypothesized to be generally controlled by temperature, phosphorus, and iron availability in the global ocean. However, even in the North Atlantic where most research on diazotrophs and $\mathrm{N}_{2}$ fixation has taken place, environmental controls remain contentious. Here we measure diazotroph composition, abundance, and activity at high resolution using newly developed underway sampling and sensing techniques. We capture a diazotrophic community shift from Trichodesmium to UCYN-A between the oligotrophic, warm $\left(25-29^{\circ} \mathrm{C}\right)$ Sargasso Sea and relatively nutrient-enriched, cold $\left(13-24{ }^{\circ} \mathrm{C}\right)$ subpolar and eastern American coastal waters. Meanwhile, $\mathrm{N}_{2}$ fixation rates measured in this study are among the highest ever recorded globally and show significant increase with phosphorus availability across the transition from the Gulf Stream into subpolar and coastal waters despite colder temperatures and higher nitrate concentrations. Transcriptional patterns in both Trichodesmium and UCYN-A indicate phosphorus stress in the subtropical gyre. Over this iron-replete transect spanning the western North Atlantic, our results suggest that temperature is the major factor controlling the diazotrophic community structure while phosphorous drives $\mathrm{N}_{2}$ fixation rates. Overall, the occurrence of record-high UCYN-A abundance and peak $\mathrm{N}_{2}$ fixation rates in the cold coastal region where nitrate concentrations are highest $(\sim 200 \mathrm{nM})$ challenges current paradigms on what drives the distribution of diazotrophs and $\mathrm{N}_{2}$ fixation.
\end{abstract}

\section{Introduction}

Nitrogen $\left(\mathrm{N}_{2}\right)$ fixation, conducted by a group of specialized microorganisms called diazotrophs, provides the largest

Supplementary information The online version of this article (https:// doi.org/10.1038/s41396-020-0703-6) contains supplementary material, which is available to authorized users.

Julie Robidart

j.robidart@noc.ac.uk

$\triangle$ Nicolas Cassar

Nicolas.Cassar@duke.edu

1 Division of Earth and Ocean Sciences, Nicholas School of the Environment, Duke University, Durham, NC 27708, USA

2 Department of Ocean and Earth Sciences, National Oceanography Centre, University of Southampton, European Way, SO14 3ZH Southampton, UK external nitrogen input into the ocean [1,2]. Alleviating nitrogen limitation over a large portion of the global surface oceans, $\mathrm{N}_{2}$ fixation supports new production and net oceanic carbon uptake $[3,4]$. Over geological time scales, $\mathrm{N}_{2}$ fixation is believed to compensate for nitrogen removal from denitrification and anammox [5]. The balance between these microbial processes influences oceanic productivity, export of carbon to the deep ocean and ultimately

CNRS, Univ Brest, IRD, Ifremer, LEMAR, F-29280 Plouzané, France

4 Ocean Technology and Engineering Group, National Oceanography Centre, European Way, SO14 3ZH Southampton, UK

5 Present address: Department of Geosciences, Princeton University, Princeton, NJ 08544, USA

6 Present address: Department of Earth, Ocean and Ecological Sciences, School of Environmental Sciences, University of Liverpool, Liverpool L69 3GP, UK 


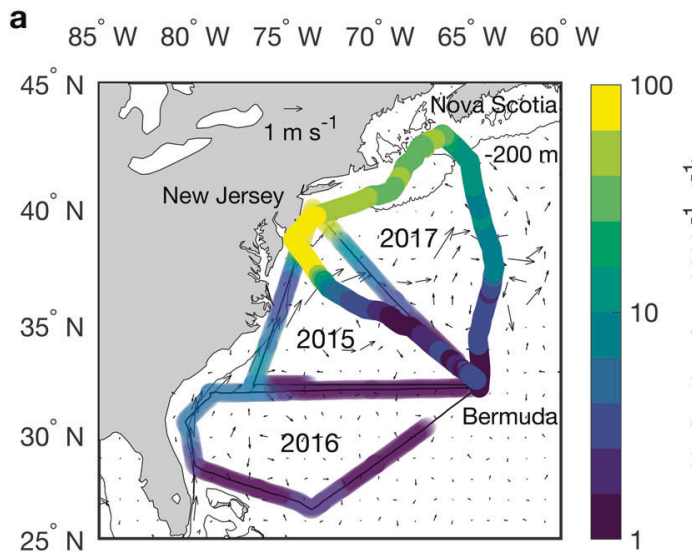

Fig. $1 \mathbf{N}_{\mathbf{2}}$ fixation rates and molecular sampling sites. a $\mathrm{N}_{2}$ fixation rates (colored points) observed in 2017 summer are compared to $\mathrm{N}_{2}$ fixation rates (transparent colored points) measured in 2015 and 2016 summers (obtained from Tang et al. [23]), superimposed over surface currents (arrows) derived from satellite-observed sea surface height (CMEMS) during the 10-day 2017 cruise. The strong surface currents show the rough position of the Gulf Stream and the solid black line depicts the $200 \mathrm{~m}$ bathymetry (ETOPO1). b Robotic

atmospheric $\mathrm{CO}_{2}$ concentrations [6, 7]. Therefore, understanding the factors regulating $\mathrm{N}_{2}$ fixation and diazotrophs is important for evaluating and predicting changes to nitrogen and carbon cycling in the global ocean.

The dominant environmental controls on $\mathrm{N}_{2}$ fixation rates and diazotrophs in the global ocean remain elusive. Various factors have been proposed as controls, including temperature [8], phosphorus [9], iron [10], nutrient supply ratios [11], zooplankton grazing [12], and a combination of multiple factors [13, 14]. Specifically, warm and oligotrophic subtropical waters enriched in iron while depleted in nitrogen are traditionally recognized as hot spots of $\mathrm{N}_{2}$ fixation and diazotrophs [11, 15]. In the North Atlantic, phosphorus and iron availability are believed to be the major factors regulating diazotroph distribution and activity $[9,14,16-18]$. However, observations used in these analyses are mostly distributed in the central and eastern North Atlantic, leaving the western and temperate North Atlantic relatively undersampled. In addition, although pioneering studies on $\mathrm{N}_{2}$ fixation date back to the 1960s in the Sargasso Sea [19], much of the early work focused on large-size Trichodesmium colonies captured via plankton nets [20]. This sampling technique may overlook the potential role of small unicellular cyanobacterial (e.g., UCYN-A) and noncyanobacterial diazotrophs, whose importance has become increasingly recognized [21, 22]. Thus, aside from Trichodesmium, the diazotrophic community in the western North Atlantic remains poorly characterized. Since $\mathrm{N}_{2}$ fixation is the cumulative product of the diazotrophic activity of different microorganisms, a more comprehensive characterization of diazotrophs is required to resolve b $80^{\circ} \mathrm{W} \quad 75^{\circ} \mathrm{W} \quad 70^{\circ} \mathrm{W} \quad 65^{\circ} \mathrm{W} \quad 60^{\circ} \mathrm{W}$

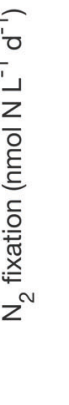

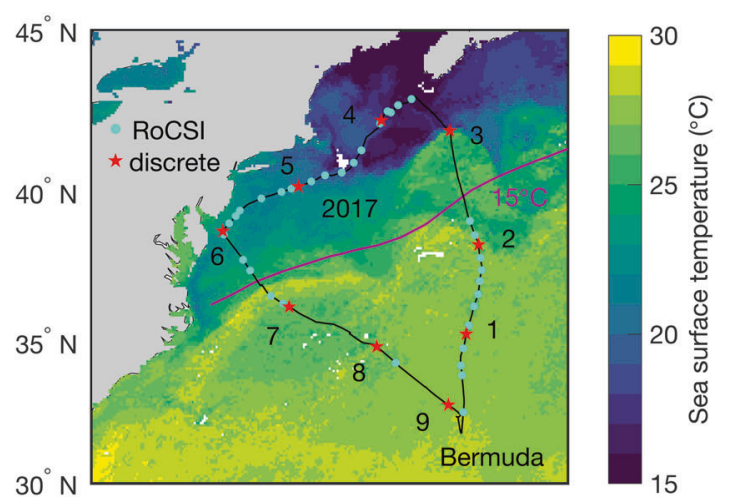

Cartridge Sampling Instrument-RoCSI samples (cyan circles) and discrete daily noon samples (number $1-9$, red stars) are overlaid over satellite mean sea surface temperatures (MODIS-Aqua) observed during the 10-day 2017 cruise. The subpolar gyre and subtropical gyre are separated by the north wall of the Gulf Stream (purple line) which is defined as the intersection of the $15^{\circ} \mathrm{C}$ isotherm with the $200 \mathrm{~m}$ isobaths [48].

the environmental controls on $\mathrm{N}_{2}$ fixation in the North Atlantic.

To that end, our study builds on the survey of $\mathrm{N}_{2}$ fixation in Tang et al. [23], revisits the hot spots along the US Eastern Seaboard, and extends observations to higher latitudes $\left(30-43^{\circ} \mathrm{N}\right)$ using a method we recently developed to estimate $\mathrm{N}_{2}$ fixation continuously [24]. We couple these measurements with a newly developed high-frequency autonomous microbial molecular sampling approach to contextualize these rates with diversity and gene expression patterns of $\mathrm{N}_{2}$-fixing organisms (Robidart et al., unpublished). This unprecedented combination of high-resolution $\mathrm{N}_{2}$-fixation observations and molecular sampling allows us to capture and characterize episodic diazotrophic blooms and evaluate their environmental controls.

\section{Materials and methods}

\section{Sample collection and analyses}

During a 10-day cruise between July 29 and August 7, 2017 traveling north from Bermuda to the Nova Scotia coast, then south to the New Jersey coast and finally back to Bermuda (Fig. 1), surface seawater $(\sim 5 \mathrm{~m})$ was continuously pumped via a trace metal clean tow-fish system (GeoFish, manufactured by University of California Santa Cruz) into the laboratory aboard the $R / V$ Atlantic Explorer [25]. This seawater was used for nutrient, trace metal, and microbial molecular sample collection and for $\mathrm{N}_{2}$ fixation incubations. Nutrients (nitrate + nitrite and phosphate) 
were sampled in acid-washed $15 \mathrm{ml}$ polypropylene tubes (Falcon, Corning, USA) and immediately preserved in a $-20{ }^{\circ} \mathrm{C}$ freezer. Nutrients were then analyzed colorimetrically with an automatic nutrient analyzer on land [26, 27]. The detection limits for nitrate + nitrite and phosphate were $0.01 \mu \mathrm{M}$ and $0.014 \mu \mathrm{M}$, respectively. The trace metal samples were collected directly in a laminar flow hood within a custom-built clean bubble. Samples were filtered through $0.2 \mu \mathrm{m}$ cartridge filters (Sartobran 300 , Sartorius, Germany) into $60 \mathrm{ml}$ LDPE bottles cleaned following GEOTRACES protocols [28]. Samples for dissolved manganese $(\mathrm{DMn})$, copper $(\mathrm{DCu})$ and iron $(\mathrm{DFe})$ were acidified on board with $\mathrm{HCl}$ (ultrapure, Merck), then stored at ambient temperature and finally analyzed by SFICP-MS back in the lab on land [29]. A detailed description of the trace metal sampling and analyses can be found in Tang et al. [23].

\section{Measurement of $\mathrm{N}_{2}$ fixation, primary production, and net community production rates}

Surface $\mathrm{N}_{2}$ fixation rates shown in Fig. 1a were measured continuously underway via Flow-through incubation Acetylene Reduction Assay by CAvity ring-down Spectroscopy (FARACAS) [24]. Briefly, acetylene $\left(\mathrm{C}_{2} \mathrm{H}_{2}\right)$ is dissolved into filtered seawater and is then mixed with surface seawater collected continuously via a tow-fish, reaching a $10 \%$ $\mathrm{C}_{2} \mathrm{H}_{2}$ saturation. The mixed seawater is pumped into a $9 \mathrm{~L}$ flow-through incubation chamber at $\sim 100 \mathrm{ml} \mathrm{min}^{-1}$ leading to a 90 min residence time for the flow-through seawater. After incubation, the ethylene $\left(\mathrm{C}_{2} \mathrm{H}_{4}\right)$ from the incubated seawater is extracted by a bubble column reactor using a $\sim 35 \mathrm{ml} \mathrm{min}^{-1} \mathrm{C}_{2} \mathrm{H}_{4}$-free stripping gas and then measured by cavity ring-down spectroscopy (CRDS). CRDS measures $\mathrm{C}_{2} \mathrm{H}_{4}$ concentration every few seconds at high precision. Bypassing the incubation chamber every few hours, $\mathrm{C}_{2} \mathrm{H}_{4}$ background in the mixture of $\mathrm{C}_{2} \mathrm{H}_{4}$ tracer and seawater is determined. The $\mathrm{C}_{2} \mathrm{H}_{4}$ concentration difference between incubation and bypass can be used to calculate the near realtime $\mathrm{C}_{2} \mathrm{H}_{4}$ production rates. Finally, the $\mathrm{C}_{2} \mathrm{H}_{4}$ production rates are converted to $\mathrm{N}_{2}$ fixation rates using a 4:1 ratio. The detection limit of FARACAS is $\sim 0.19 \mathrm{nmol} \mathrm{N} \mathrm{L}^{-1} \mathrm{~d}^{-1}$, which is comparable to the discrete ${ }^{15} \mathrm{~N}_{2}$ addition method. Surface $\mathrm{N}_{2}$ fixation and primary production rates at 22 discrete stations were measured in triplicate using the dissolved ${ }^{15} \mathrm{~N}_{2}$ and ${ }^{13} \mathrm{C}$ addition methods. The detailed description of the isotope incubation protocols can be found in Berthelot et al. [30]. $\mathrm{N}_{2}$ fixation rates were considered as detected when the isotopic enrichment was higher than 0.00146 atom\% [31]. This led to detection limit ranging $0.11-2.23 \mathrm{nmol} \mathrm{L}^{-1} \mathrm{~d}^{-1}$ (depending on the particulate $\mathrm{N}$ collected on filters). Using this criterion, $\mathrm{N}_{2}$ fixation was detected at 21 of the 22 stations.
Net community production (NCP) rates were concurrently estimated based on continuous dissolved $\mathrm{O}_{2} / \mathrm{Ar}$ measurements by equilibrator inlet mass spectrometry [32]. Since $\mathrm{O}_{2}$ and Ar have similar solubility properties while $\mathrm{Ar}$ is biologically inert, Ar-normalized $\mathrm{O}_{2}$ can infer biological $\mathrm{O}_{2}$ production by removing physical influences on $\mathrm{O}_{2}$ concentration [33]. NCP represents the difference between primary production and community respiration, which can be used as a proxy for new production and/or export production. The contribution of $\mathrm{N}_{2}$ fixation to NCP was assessed by estimating their carbon fixation potentials with conversion factors of $\mathrm{C}: \mathrm{N}=106: 16$ and $\mathrm{C}: \mathrm{O}_{2}=1: 1.4$ following Tang et al. [23]. Assuming constant C:N and C: $\mathrm{O}_{2}$ ratios introduces uncertainties in our estimates. However, while variation in the conversion factors may affect the absolute contribution of $\mathrm{N}_{2}$ fixation to $\mathrm{NCP}$, they have smaller effects on the spatial pattern.

\section{Molecular sampling}

Over 200 molecular samples were collected at high frequency using a newly developed autonomous filtration system: Robotic Cartridge Sampling Instrument-RoCSI (Robidart et al., unpublished) (Fig. 1b). Briefly, around 2 L of seawater taken from the tow-fish system was filtered through a $0.2 \mu \mathrm{m}$ Sterivex filter (Millipore, MA, USA) approximately every hour. The Sterivex filters were immediately preserved by adding RNAlater solution and stored at room temperature until transferred to a $-80^{\circ} \mathrm{C}$ freezer within $24 \mathrm{~h}$. In addition to hourly sampling by RoCSI, we collected over 100 discrete molecular samples in triplicate nearly every 6 hours (i.e. $\sim 4$ times daily) from surface underway line and from 10 CTD stations. Depending on particle concentrations and biomass, $\sim 1.5 \mathrm{~L}$ to over $4 \mathrm{~L}$ of seawater was filtered on each Sterivex filter using a peristaltic pump. The Sterivex filters were flashfrozen in liquid nitrogen and stored at $-80^{\circ} \mathrm{C}$. These filters were later used for DNA and RNA analyses. Data obtained from 34 RoCSI samples as well as 9 discrete molecular samples collected at around noon local time daily are presented in this study (Fig. 1b).

\section{DNA and RNA extractions}

DNA and RNA were extracted from the Sterivex filters using the AllPrep DNA/RNA Mini kit (Qiagen, MD, USA), including an initial bead-beating step $(2 \mathrm{~min}$ at $30 \mathrm{~Hz}$ in a Qiagen TissueLyser) in RLT + buffer before following the manufacturer's instructions. DNA was digested from RNA samples using a RNase-free DNase set (Qiagen, MD, USA) and the RNA Clean \& Concentrator kit (Zymo, CA, USA). DNA and RNA were eluted in $50 \mu \mathrm{l}$ EB buffer and $50 \mu \mathrm{l}$ 
RNase-free water respectively. The DNA and RNA extracts were quantified using the Qubit ${ }^{\mathrm{TM}}$ DNA/RNA HS Assay Kit (Invitrogen, CA, USA) according to the manufacturer's guidelines. In addition, RNA purity and integrity were checked using RNA chips on an Agilent 2100 Bioanalyser (Agilent, CA, USA).

\section{nifH PCR amplification, amplicon sequencing, and sequence analysis}

Diazotrophic communities were characterized by sequencing nifH genes from nine discrete samples collected at around noon during the cruise (Fig. 1b). DNA extracted from stations 7, 8 and 9 were pooled together due to their low DNA concentrations. nifH genes were amplified using a nested PCR protocol [34], using second round PCR primers (nifH1 and nifH2) containing Illumina tag sequences (Supplementary Table 1). nifH amplification and PCR conditions are described in Turk et al. [35]. Equimolar concentrations of nifH amplicons were pooled and sequenced using the Miseq-Illumina platform at the University of Southampton's Environmental Sequencing Facility. The sequencing data have been deposited in the NCBI Sequence Read Archive under accession number PRJNA554315.

We used QIIME1 to process the amplicon sequencing data [36]. Raw sequences were merged and quality filtered, whereby sequences with a quality score $<20$, expected number of errors $>1$, and reads $<200$-bp long were removed using USEARCH [37]. On average, 37,366 sequences per sample were obtained after quality control $(\mathrm{min}=33,500$ and $\max =43,333)$. Sequences were further clustered into operational taxonomic units (OTUs) at 97\% sequence identity after removing chimeras via UPARSE [38]. Representative sequences from nifH OTUs were assigned putative taxonomies using the BLAST resource on NCBI yielding a final dataset of 550 OTUs.

\section{Quantification of nifH gene copies and nifH gene expression}

The abundance and expression of nifH genes from selected major diazotroph taxa were quantified using quantitative PCR (qPCR) and reverse transcription qPCR (RT-qPCR), including Trichodesmium, UCYN-A, and Crocosphaera [39]. Complementary DNA (cDNA) was synthesized from purified RNA using the QuantiTect Reverse Transcription Kit (Qiagen, MD, USA) following the manufacturer's guidelines, using equimolar quantities $(0.25 \mu \mathrm{M})$ of nifH2 and nifH3 primers [35] and $10 \mathrm{ng}$ of purified RNA extract. Negative controls (no-RTs) were generated for each sample in parallel. Protocol of qPCR reaction conditions and thermocycling parameters are described in Robidart et al. [40].
Briefly, the reactions were prepared in 96-well optical reaction plates with optical caps (Applied Biosystems, CA, USA) and run on a Real-time PCR System (Roche LightCycler 96 Instrument, Germany) with the following thermocycling settings: $95{ }^{\circ} \mathrm{C}$ for $75 \mathrm{~s}, 45$ cycles of $94{ }^{\circ} \mathrm{C}$ for $15 \mathrm{~s}$ and $59^{\circ} \mathrm{C}$ for $30 \mathrm{~s}$. The sample reactions $(30 \mu \mathrm{l})$ were run in triplicate or duplicate and contained $15 \mu \mathrm{l}$ of AccuPrime $^{\mathrm{TM}}$ SuperMix I (Invitrogen, CA, USA), $2.4 \mu \mathrm{l}$ of $25 \mathrm{mM} \mathrm{MgCl}_{2}$ solution, $9.86 \mu \mathrm{l}$ of nuclease-free water (Ambion, CA, USA), $0.12 \mu \mathrm{l}$ each of the forward and reverse primers $(0.4 \mu \mathrm{M}$ final concentration), $0.5 \mu \mathrm{l}$ of FAM-labeled TaqMan probe $(0.2 \mu \mathrm{M}$ final concentration) and $2 \mu \mathrm{l}$ of template DNA. Standard dilution series ranging from $10^{0}$ to $10^{7}$ gene copies were used for each reaction. Negative controls with $2 \mu$ of nuclease-free water (Ambion, CA, USA) instead of the template DNA were run on each plate to check for contamination. No amplification was observed across all negative controls. Samples with no amplification are denoted as below the detection limit (35-133 copies $\mathrm{L}^{-1}$ ) while samples with only one or two amplifications in a triplicate run are denoted as detectable but not quantifiable. The efficiency of the qPCR and RTqPCR reactions ranged from $98.6 \%$ to $107.2 \%$, with an average of $103.7 \%$.

\section{RT-qPCR of phosphorus stress marker gene expression in diazotrophs}

To characterize the physiological status of diazotrophs, we designed primers and standards targeting the $p s t S$ gene for phosphorus stress for both Trichodesmium and UCYN-A (Supplementary Table 1). UCYN-A pstS genes were collected from GenBank and aligned. Sequences were highly conserved and qPCR primers were designed directly from these sequences. For Trichodesmium, a metatranscriptomic sequence database from the Atlantic Ocean was used to collect $p s t S$ genes. They were aligned with pstS genes from GenBank, and qPCR assays were designed based on conserved regions in the gene. Genes were amplified from cruise samples and cloned as described below.

$p s t S$ amplicons were ligated to the pGEM T-Easy vector and cloned into TOP10 cells (Invitrogen). Plasmids were purified from cultured clones and sequenced to confirm specificity. Sequenced plasmids were used as standards. Standard curves from $10^{0}-10^{7}$ copies were run on each plate with cDNA/DNA extracts from the cruise, and standard curve efficiencies were $103.2 \%$ (Trichodesmium) and 99.2\% (UCYN-A). In addition to sequencing from the cruise samples, specificity was determined by comparing nifH copy numbers to pstS copy numbers (Supplementary Fig. 1), with the expectation that there should be a 1:1 relationship if primer sets are specific $(n=7, r=0.99$, 

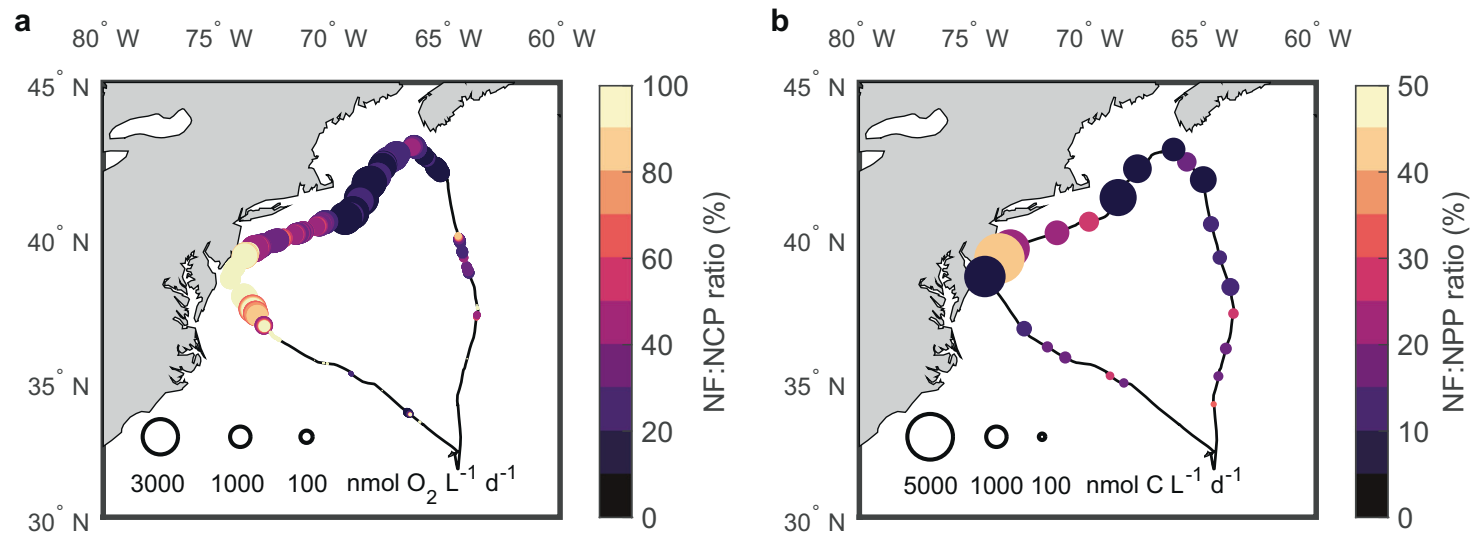

Fig. 2 Contribution of $\mathbf{N}_{2}$ fixation (NF) to marine production. Contribution of NF to a net community production (NCP) and $\mathbf{b}$ net primary production (NPP). The circle size represents the magnitude of NCP and NPP.

$q<0.01)$. pstS gene expression was quantified using RTqPCR to evaluate potential nutrient limitation in diazotrophs collected near noon across large spatial gradients (stations 1-9). We normalized pstS transcription per liter seawater to the diazotroph nifH gene abundances per liter, and we reported both transcripts per liter and transcripts per nifH copy for Trichodesmium and UCYN-A.

\section{Results and discussion}

\section{Distribution of $\mathbf{N}_{2}$ fixation rates}

Large spatial variations in surface $\mathrm{N}_{2}$ fixation rates were observed in the northwestern North Atlantic, ranging from below the detection limit $\left(0.19 \mathrm{nmol} \mathrm{N} \mathrm{L}^{-1} \mathrm{~d}^{-1}\right)$ to over 167 nmol N L ${ }^{-1} \mathrm{~d}^{-1}$ (Fig. 1). FARACAS $\mathrm{N}_{2}$ fixation (gross rate) measurements agreed strongly with the results of discrete ${ }^{15} \mathrm{~N}_{2}$ incubations (net rate) over a wide range of rates ( $n=$ 22, $r=0.7, p<0.01$; Supplementary Fig. 2). While the warm and oligotrophic Sargasso Sea is traditionally believed to harbor conditions favorable to $\mathrm{N}_{2}$ fixation, we found relatively low $\mathrm{N}_{2}$ fixation rates across this region (geometric mean of $3 \mathrm{nmol} \mathrm{N} \mathrm{L}{ }^{-1} \mathrm{~d}^{-1}$ ). $\mathrm{N}_{2}$ fixation can however still occasionally support a large fraction of local $\mathrm{NCP}$ and net primary production (NPP) due to lower NCP and NPP offshore (Fig. 2).

High $\mathrm{N}_{2}$ fixation rates were primarily located in cold subpolar North Atlantic and coastal waters from Nova Scotia to the Mid-Atlantic Bight (geometric mean of 43 nmol N L ${ }^{-1} \mathrm{~d}^{-1}$ ). These waters were more nutrient rich than the adjacent subtropical waters. Intense $\mathrm{N}_{2}$ fixation in coastal waters has recently been reported by Tang et al. [23]. However, such high $\mathrm{N}_{2}$ fixation rates as we observed in the subpolar North Atlantic have rarely been detected in other subpolar oceans, deserving further exploration.
$\mathrm{N}_{2}$ fixation has been reported at measurable rates in the Arctic Ocean [41, 42] and in temperate areas [43]. The elevated rates that we measured off the cold Nova Scotia coast (above $25 \mathrm{nmol} \mathrm{N} \mathrm{L}^{-1} \mathrm{~d}^{-1}$ in $13{ }^{\circ} \mathrm{C}$ seawater) further extends the distribution of high $\mathrm{N}_{2}$ fixation rates (Fig. 1). Our observation of disproportionately large $\mathrm{N}_{2}$ fixation fluxes in subpolar and coastal waters confirms the high contribution of $\mathrm{N}_{2}$ fixation in North American continental shelf waters, which Mulholland et al. [44] estimated to be $0.28 \mathrm{Tg} \mathrm{N} \mathrm{yr}^{-1}$ between Cape Hatteras and Nova Scotia. Estimates of $\mathrm{N}$ inputs from $\mathrm{N}_{2}$ fixation in the North Atlantic range between 4.3 and $89.6 \mathrm{Tg} \mathrm{N} \mathrm{yr}^{-1}$ [45], and have mostly been derived from tropical and subtropical regions. Our results argue for the inclusion of coastal $\mathrm{N}_{2}$ fixation when estimating regional and global $\mathrm{N}_{2}$ fixation fluxes, and for the inclusion of $\mathrm{N}_{2}$ fixation, rarely considered in coastal studies [46, 47], when evaluating $\mathrm{N}$ budgets in coastal waters.

Intensive $\mathrm{N}_{2}$ fixation activity observed near the New Jersey coast reached the top $1 \%$ of $\mathrm{N}_{2}$ fixation rates ever reported in the literature [49]. The annual recurrence of these diazotrophic blooms (observed in 2015 and 2017 summers shown in Fig. 1a) makes this region one of the most significant $\mathrm{N}_{2}$ fixation hot spots in the global ocean, alongside the tropical North Atlantic [20], the western tropical South Pacific [50] and the coast of the eastern Arabian Sea [51, 52]. However, we only captured a snapshot of this diazotrophic hotspot in summer as opposed to observing the full pattern of seasonal variability. Recent studies have started to shed light on the temporal patterns of $\mathrm{N}_{2}$ fixation in the western North Atlantic coastal waters: the peak season of $\mathrm{N}_{2}$ fixation ranges from spring to fall depending on the location [44]. The mechanisms driving such seasonality remain unclear, warranting further study. Phytoplankton blooms in the Mid-Atlantic Bight are generally thought to be enhanced by nutrients supplied from 
physical mixing, upwelling [53], and riverine runoff [54]. Here we demonstrated that $\mathrm{N}_{2}$ fixation could also be an important source of new nitrogen, contributing substantially to both NCP $(>80 \%)$ and NPP (>30\%) in this area (Fig. 2). We should however interpret the fraction of NCP fueled by $\mathrm{N}_{2}$ fixation with caution because of differences in the integration time scales of our methods. FARACAS estimates hourly and daily $\mathrm{N}_{2}$ fixation rates while $\mathrm{O}_{2} / \mathrm{Ar}-\mathrm{NCP}$ observations integrate productivity over a few days in this region. However, simultaneous measurements of $\mathrm{N}_{2}$ fixation and NPP in ${ }^{15} \mathrm{~N}_{2}$ - and ${ }^{13} \mathrm{C}$-addition incubations, shown in Fig. 2b, avoid the issue of reconciling different measurement time scales and corroborate the role of $\mathrm{N}_{2}$ fixation in the supporting coastal marine production. $\mathrm{N}_{2}$ fixation and marine production are thus closely linked, albeit with significant spatial variations in the western North Atlantic (the contribution of $\mathrm{N}_{2}$ fixation to NPP ranged from $5.6 \%$ to $42 \%$ ). These results also underline the need to further investigate $\mathrm{N}_{2}$ fixation in poorly sampled and unexplored regions.

\section{Diazotrophic communities}

During the transition from regions of low to high $\mathrm{N}_{2}$ fixation, the diazotrophic community shifted dramatically from Trichodesmium and non-cyanobacterial diazotrophs (e.g., $\gamma$ -24774A11) in the subtropical gyre to UCYN-A in the subpolar gyre and coastal areas (Fig. 3). Trichodesmium accounted for over $50 \%$ of nifH gene sequences at stations $1-2$. In contrast, UCYN-A constituted a majority portion of nifH gene sequences at stations 3-5. One of the unidentified diazotrophs observed in the subtropical gyre matched an organism (accession number: AF016613.2 in NCBI) sampled within the same region reported in Zehr et al. (1998) [55]. Over our study area, low $\mathrm{N}_{2}$ fixation rates were observed when non-cyanobacterial diazotrophs were abundant. In addition, Crocosphaera and Richelia were not detected in nifH amplicon sequencing. Previous studies have also reported low Crocosphaera abundance in the North Atlantic [56]. Nevertheless, a portion of the diazotrophic community may not be amplifiable with the sequencing primers used in this study, as recent metagenomic deep sequencing has revealed diverse nifH phylotypes that would not be amplified with existing universal nifH primers [22]. Different spatial shifts of diazotrophs distribution have been previously observed in the North Atlantic [17, 57] and in the western Pacific [58, 59]. However, the factors driving such changes in diazotroph communities vary spatially. Therefore, it becomes critical to understand the conditions leading to the shift of diazotrophs and dominance of UCYN-A in coastal waters, as this organism is likely responsible for one of the highest marine $\mathrm{N}_{2}$ fixation rates ever reported.

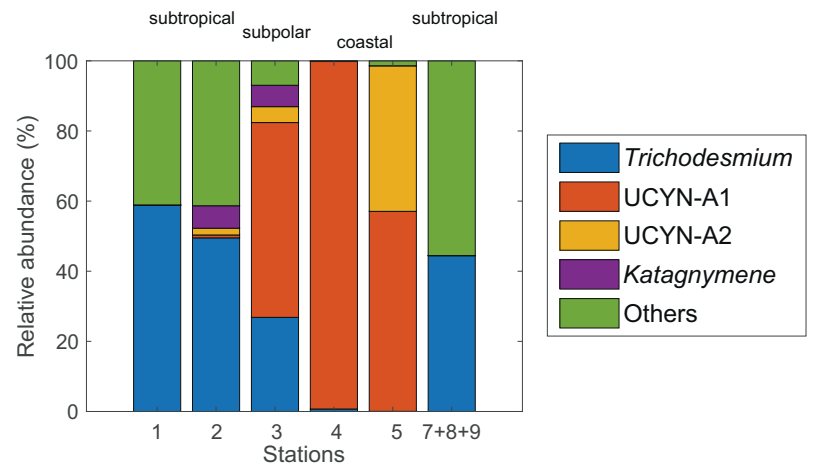

Fig. 3 Relative abundance of nifH OTUs recovered from community DNA in discrete samples collected near noon daily shown in Fig. 1b. "Others" includes non-cyanobacterial diazotrophs, unidentified diazotrophs, and unassigned sequences in NCBI (e.g., AF016613.2; CP009517.1; CP020953.1; CP001649.1; KU248161.1).

\section{Factors controlling the distribution of $\mathbf{N}_{2}$ fixation}

The spatial distribution of $\mathrm{N}_{2}$ fixation rates paralleled dissolved inorganic phosphorus (DIP) concentrations (Fig. 4 and Supplementary Fig. 3). Median $\mathrm{N}_{2}$ fixation rates were nearly 8 times higher when DIP concentration exceeded $0.05 \mu \mathrm{M}$ north of the Gulf Stream (Fig. 5). High DIP concentrations in the subpolar gyre and coastal waters may result from multiple sources including mixing and riverine runoff $[60,61]$. In contrast, DIP was depleted in the western subtropical North Atlantic [62]. Our results are consistent with modeling work suggesting phosphorus limitation of $\mathrm{N}_{2}$ fixation in the subtropical North Atlantic [63]. Although the transport of excess phosphorus across the Gulf Stream has been hypothesized to sustain $\mathrm{N}_{2}$ fixation in the subtropical North Atlantic [64], we observed relatively low $\mathrm{N}_{2}$ fixation rates that are comparable to previous estimates [49] in the subtropical North Atlantic.

Iron is another potential factor limiting $\mathrm{N}_{2}$ fixation [16]. We measured relatively high $\mathrm{DFe}$ concentrations $(0.56-1.83 \mathrm{nM})$ over our research area (Supplementary Fig. 3), similar to previous observations [65]. These DFe concentrations were generally higher than the iron halfsaturation constant for the growth of Trichodesmium [66]. While $\mathrm{N}_{2}$ fixation was highest in regions with elevated $\mathrm{DFe}$ (Fig. 5), a stoichiometric excess of $\mathrm{DFe}\left(\mathrm{Fe}^{*}=\right.$ $\mathrm{DFe}-\mathrm{R}_{\mathrm{Fe}} * \mathrm{DIP}$; where $\mathrm{R}_{\mathrm{Fe}}=0.47 \mathrm{mmol} \mathrm{DFe}: 1 \mathrm{~mol} \mathrm{DIP}$ ) [67] suggested that iron was not limiting within our study area (Supplementary Fig. 3), an implication in line with recent nutrient addition experiments in this region [68]. However, diazotrophs generally have a higher iron requirement compared to other phytoplankton, e.g., Trichodesmium's iron use efficiency is fourfold lower than phytoplankton growing on ammonium [69]. The excess $\mathrm{DFe}$ at some coastal stations could disappear (and in fact become negative, indicative of iron limitation) if we increase the DFe:DIP ratio (i.e. $\mathrm{R}_{\mathrm{Fe}}$ ) by approximately 


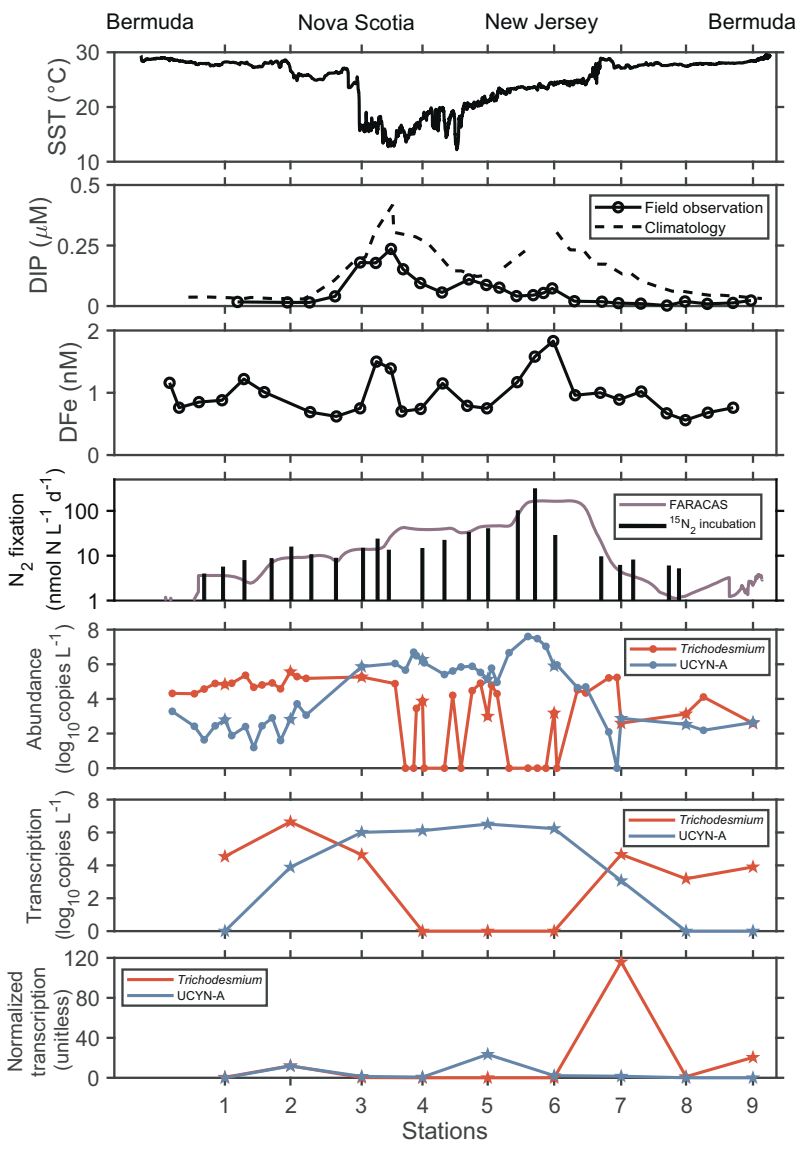

Fig. 4 Environmental properties, $\mathrm{N}_{2}$ fixation rates, diazotroph abundances, and nifH transcription patterns along the transect. Environmental properties include sea surface temperature (SST), and concentrations of dissolved inorganic phosphorus (DIP) and dissolved $\mathrm{Fe}$ (DFe). Station numbers correspond to discrete sampling sites shown in Fig. 1b. Molecular samples collected by the discrete method and by RoCSI are depicted using filled stars and circles, respectively. nifH abundances and transcription data are presented in Supplementary Tables 2 and 3. nifH abundances and transcription below the detection limits are shown as 0 on the $y$-axis. tenfold. Furthermore, iron bioavailability to microorganisms is linked to its organic complexation, rather than the total concentration. Most dissolved iron is present in strong complexes in this region [70]. However, the availability of this strongly complexed iron to diazotrophs is not well understood. Overall, we propose that a fraction of the excess phosphorus supply to the surface waters north of and near the Gulf Stream is assimilated by diazotrophs, supporting intense $\mathrm{N}_{2}$ fixation where iron is available. In contrast, the subtropical gyre harbors less $\mathrm{N}_{2}$ fixation due to phosphorus depletion (Fig. 4).

Other good predictors of $\mathrm{N}_{2}$ fixation in this study include some trace metals e.g. DCu and DMn, and chlorophyll-a concentrations ([Chl]) (Fig. 5 and Supplementary Fig. 4). Although high concentration of copper may be toxic to diazotrophs and phytoplankton [71], a positive correlation was found between $\mathrm{N}_{2}$ fixation rates and $\mathrm{DCu}$. DCu concentrations along the transect ranged from 0.68 to $4.2 \mathrm{nM}$ near the coast, typical of this region [72, 73]. However, the presence of very strong copper-complexing agents in seawater can reduce the available copper concentration to levels low enough to limit phytoplankton growth. For example, diatoms have been demonstrated to be co-limited by copper, iron, and light availability in the Northeast Pacific [74]. In addition, copper may limit denitrification activity of denitrifying bacteria [75]. Higher DCu concentrations could support denitrification in the coastal sediment and anoxic waters, removing bioavailable nitrogen and creating conditions favorable to $\mathrm{N}_{2}$ fixation. Manganese has been shown to be essential for some terrestrial $\mathrm{N}_{2}$-fixing bacteria [76, 77], but the physiological requirement for manganese in marine diazotrophs is not well understood. Manganese shares some sources with DIP in the ocean, including lithogenic dust deposition, sediments, and rivers [78, 79]. A relationship
Fig. 5 Spearman's rank correlation analyses between surface daily $\mathrm{N}_{2}$ fixation rates and environmental properties. $\mathrm{N}_{2}$ fixation rates vs a SST $(r=$ $-0.75, p<0.01)$, b surface DIN $(r=0.54, p=0.02)$, c surface DIP $(r=0.60, p<0.01)$, d surface DIP climatology in August $(r=0.72, p<0.01)$, e surface DFe $(r=0.35, p=$ $0.07), \mathbf{f}$ surface DMn $(r=0.92$, $p<0.01$ ).
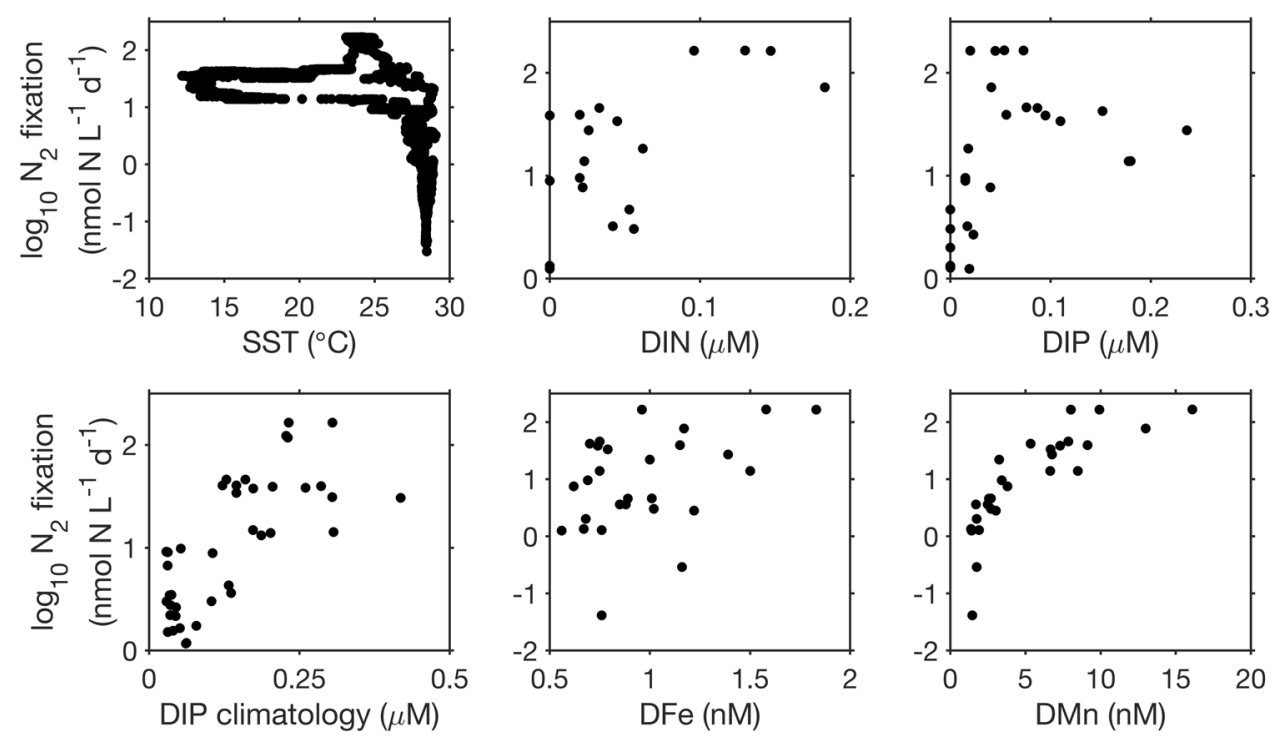
Fig. 6 Relations between quantitative diazotroph nifH gene abundances and various environmental properties. nifH abundances below detection limits are shown as 0 on the $y$-axis.
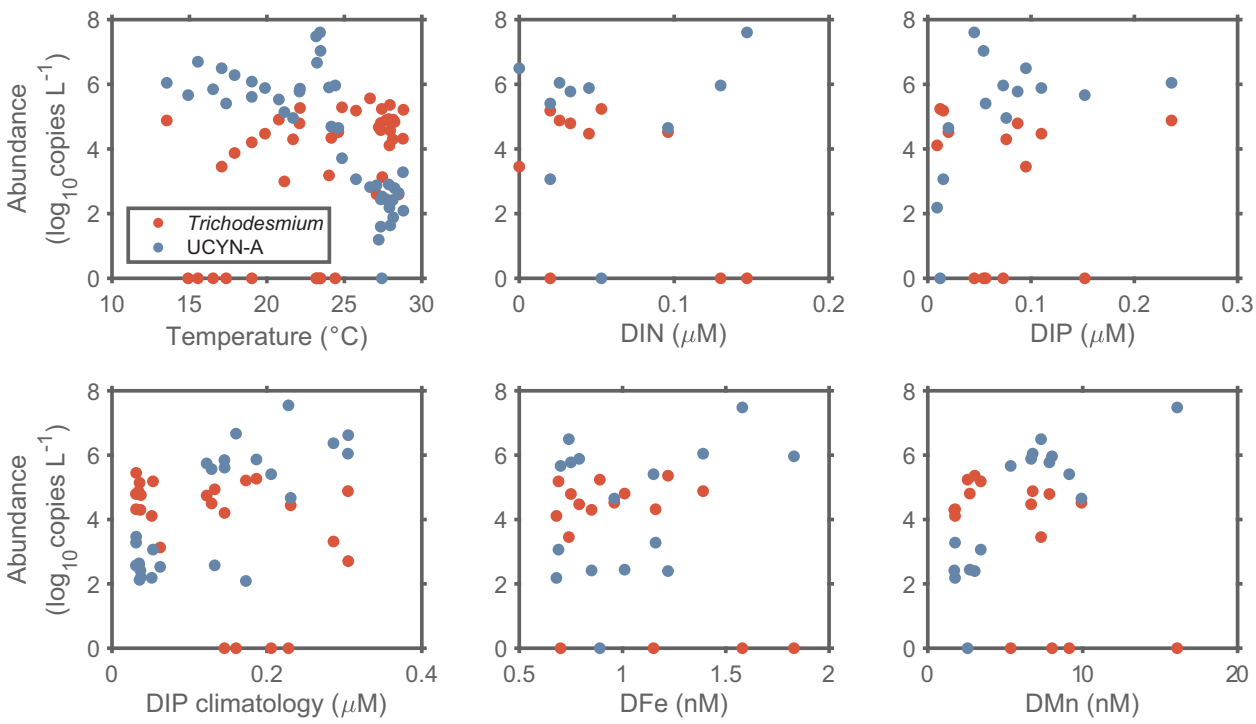

between $\mathrm{DCu}, \mathrm{DMn}$, and $\mathrm{N}_{2}$ fixation activity may simply reflect supplies of DIP and Fe or co-occurrence with other unrecognized factors beneficial to $\mathrm{N}_{2}$ fixation in our study area (Supplementary Fig. 5). Finally, $\mathrm{N}_{2}$ fixation rates were highly positively correlated to [Chl] (Supplementary Fig. 4). This result further emphasizes the presence of $\mathrm{N}_{2}$ fixation in highly productive regions $[23,80]$ in addition to in oligotrophic areas. However, it is unclear whether $\mathrm{N}_{2}$ fixation drives increases in $[\mathrm{Chl}]$ and marine production or whether $\mathrm{N}_{2}$ fixation is enhanced after depletion of nitrogen relative to phosphorus and release of organic matter by phytoplankton blooms.

\section{Factors controlling the distribution of diazotrophs}

Absolute nifH gene abundances quantified by qPCR indicate that Trichodesmium was more abundant in the subtropical gyre while UCYN-A dominated in the subpolar and coastal oceans (Fig. 4), paralleling spatial patterns of their relative abundances shown in Fig. 3. Temperature may be the dominant factor driving such community shifts, with phosphorus availability acting as a secondary influence (Fig. 6). Trichodesmium reached maximum abundances $\left(3.7 \times 10^{5}\right.$ nifH copies $\left.\mathrm{L}^{-1}\right)$ at stations 2 and 7 near or within the Gulf Stream, where seawater was warm $\left(28^{\circ} \mathrm{C}\right)$ and DIP was low. Their nifH gene transcription was also high here compared to other regions (Fig. 4). This pattern may be driven by Trichodesmium's preference for higher temperatures with an optimal growth temperature at $27^{\circ} \mathrm{C}$ [81] and their ability to exploit diverse sources of dissolved organic phosphorus [82]. Our results support findings in earlier studies [83], suggesting that the Gulf Stream serves as a transport highway for Trichodesmium. This strong current could carry Trichodesmium from the tropical Atlantic and along the Eastern American coast to temperate oceans (Supplementary Fig. 6), which may explain why Trichodesmium has been captured at high latitudes [84], e.g., near the British Isles [85]. Thus, the Gulf Stream may transport diazotrophs and nitrogen incorporated via $\mathrm{N}_{2}$ fixation in addition to its physical transport of nutrients [86]. Transport of Trichodesmium is also observed in the Kuroshio Current in the North Pacific [87], indicating the potentially widespread role of strong western boundary currents in transporting diazotrophs. Although Trichodesmium was also present in coastal and cold waters, their nifH gene transcription was undetectable (Fig. 4). This may indicate $\mathrm{N}_{2}$ fixation may not be the main $\mathrm{N}$ source for Trichodemsium in these regions. The activities and preferred nutrient strategies of Trichodesmium in the cold higher latitudes warrant further study.

In contrast, UCYN-A was more abundant in subpolar and coastal areas where temperature was low and phosphorus was more available despite the presence of nitrate. UCYN-A abundance estimated by nifH qPCR agrees with the results from quantitative 16S rRNA amplicon sequencing (Supplementary Fig. 7). UCYN-A abundance reached $4 \times 10^{7}$ copies $\mathrm{L}^{-1}$ near the New Jersey coast (Fig. 4), among the highest abundances ever reported in the literature [49]. High transcription of the nifH gene of UCYN-A in coastal waters implies an active role in $\mathrm{N}_{2}$ fixation. Therefore, the highest $\mathrm{N}_{2}$ fixation rate across our transect was likely driven by this UCYN-A bloom. The hypothesized host of UCYN-A, Braarudosphaera bigelowii, also thrived in this area (Supplementary Fig. 8), with statistical cooccurrence patterns suggesting that it plays a key role in the regional microbial community (Wang et al., unpublished). The UCYN-A/B. bigelowii association has recently been reported in the waters off the coasts of 

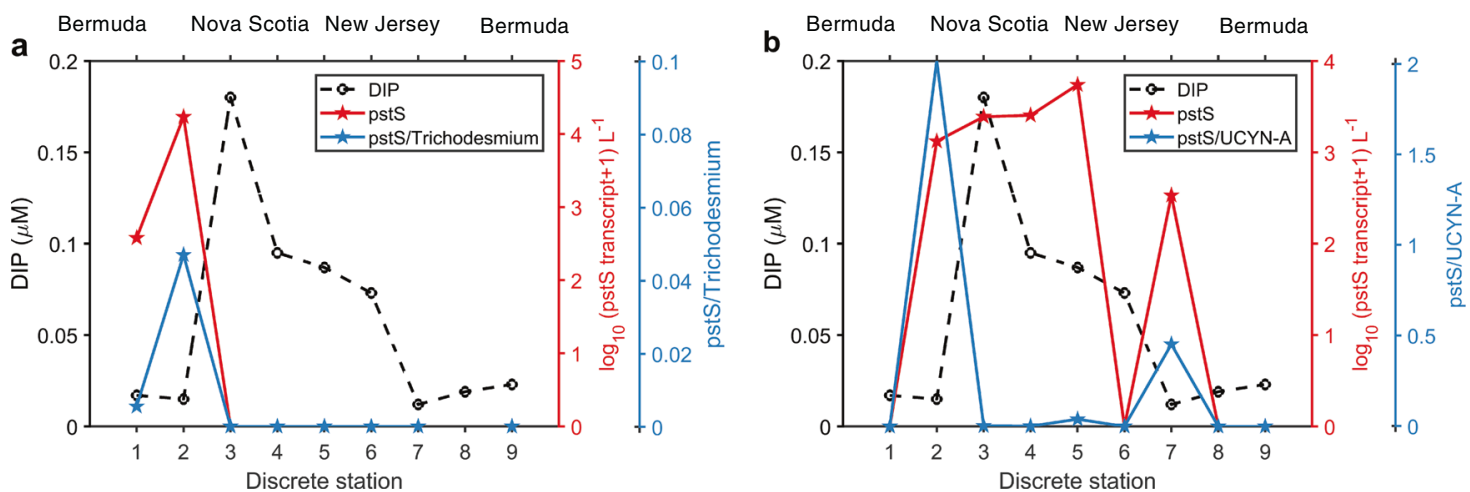

Fig. 7 Evidence suggesting phosphorus limitation in diazotrophs. Phosphorus stress patterns in a Trichodesmium and b UCYN-A at nine discrete stations shown in Fig. 1b. pstS transcription data are presented in Supplementary Table 2.

California [88] and Brazil [89], suggesting a widespread distribution.

UCYN-A was more abundant in waters with higher DIP concentrations $(>0.05 \mu \mathrm{M})$ (Fig. 6). This is consistent with Robidart et al. [40] at DIP concentrations below $0.2 \mu \mathrm{M}$ in the North Pacific but contradicts the findings of Stenegren et al. [58] who showed a negative correlation between UCYN-A abundance and DIP concentration globally. This discrepancy highlights our limited understanding of the yet-uncultivated UCYN-A group, motivating further physiological observations. The highest UCYN-A abundance observed during our cruise occurred in $\sim 24^{\circ} \mathrm{C}$ seawater, in line with its predicted optimal temperature [8] and observed niches in the eastern Atlantic [56]. However, our observations revealed high abundances $\left(>10^{6}\right.$ copies $\left.\mathrm{L}^{-1}\right)$ and expression $\left(>10^{5}\right.$ copies $\left.\mathrm{L}^{-1}\right)$ in colder environments with temperatures as low as $13{ }^{\circ} \mathrm{C}$ near Nova Scotia (Figs. 4 and 6). This is also consistent with a recent report of UCYN-A actively fixing $\mathrm{N}_{2}$ in the cold waters of the Arctic Ocean [90]. These unexpected findings expand the temperature-based distribution of active diazotrophs. Some models may consequently be underestimating the $\mathrm{N}_{2}$ fixation budget by setting the threshold for $\mathrm{N}_{2}$ fixation based on the temperature ecophysiology of Trichodesmium, overlooking the role of other diazotrophs in temperate and polar regions. Similarly, the influence of nitrate on $\mathrm{N}_{2}$ fixation in models may need to be revised. Peak $\mathrm{N}_{2}$ fixation and UCYN-A abundance were found in coastal waters with nitrate and nitrite concentrations close to $200 \mathrm{nM}$ (Figs. 5 and 6), reaching or exceeding half-saturation values of nitrate uptake in many marine phytoplankton cultures [91] and in natural phytoplankton assemblages from oceanic waters [92]. Several mechanisms have been hypothesized to explain $\mathrm{N}_{2}$ fixation in the presence of the reactive nitrogen [93-96] but the control of reactive nitrogen on UCYN-A and its hypothesized hosts deserves further investigation. Finally, iron enrichment may provide another advantage for UCYN-
A to flourish in coastal waters while the effect from cooccurrent manganese is poorly understood (Fig. 6).

Overall, the shift in diazotrophic community structure between subtropical, subpolar and coastal waters and its relation to corresponding changes of environmental controls was further confirmed and visualized by a redundancy analysis (Supplementary Fig. 9): temperature predominantly determined diazotroph composition, with phosphorus and iron playing regulatory roles.

\section{Expression patterns of an inorganic phosphorus stress marker gene in diazotrophs}

We further evaluated the nutrient stress experienced by the dominant diazotrophs by examining the transcription of the inorganic phosphorus stress biomarker pstS [97]. pst $S$ codes for a phosphate-binding subunit of the transporter PstS and has been used to show Trichodesmium's phosphorus stress in the North Atlantic subtropical gyre [98]. pstS expression in Trichodesmium was only detected in the subtropical gyre with the highest transcription observed at station 2 (Fig. 7a). In contrast, UCYN-A exhibited high pstS transcription in subpolar and coastal seawaters where DIP concentration was higher (Fig. 7b). However, pstS transcription normalized to nifH gene abundance was significantly lower in these subpolar and coastal regions compared to the subtropical gyre, indicating that phosphorus limitation may be stronger in the subtropical regions where DIP was depleted. Organic phosphorus concentrations were not measured on this cruise, but may also play a role. Both Trichodemsium and UCYN-A may have highest inorganic phosphorus stress in the subtropical waters, but Trichodesmium are able to assimilate organic forms of phosphorus to mitigate phosphorus stress in the North Atlantic subtropical gyre [98]. In addition to assessing the phosphorus stress, future work should target marker gene expression indicative of iron limitation. 


\section{Conclusion}

By applying high-resolution biogeochemical and biological sampling techniques, we captured the large-scale distribution of $\mathrm{N}_{2}$ fixation and diazotrophs from the subtropical North Atlantic to the US East Coast, with contrasting patterns between Trichodesmium and UCYN-A, the dominant diazotrophs in this study. The overlooked high $\mathrm{N}_{2}$ fixation fluxes in the subpolar gyres and in coastal oceans could be significant contributors to global marine $\mathrm{N}_{2}$ fixation. Substantial variations in diazotroph abundance over short distances were observed thanks to our high-frequency sampling techniques, further demonstrating the patchy spatial distribution of diazotrophs. Further, record abundances of UCYN-A quantified here are largely attributed to the high-resolution sampling scheme detecting bloom conditions, which would have been less likely to be captured by the traditional discrete CTD sampling.

Strong gradients in physical and chemical factors enabled the clear attribution of ecological drivers for $\mathrm{N}_{2}$ fixation and diazotrophs. Dramatic changes in $\mathrm{N}_{2}$ fixation rates (from undetectable to the highest $1 \%$ of rates measured globally) and shifts in diazotrophic community structure were best explained by phosphorus availability and temperature gradients, respectively. Taken together, our results imply that the environmental controls on $\mathrm{N}_{2}$ fixation rates and diazotroph composition may be different, with the best predictors of diazotroph abundances varying across species. For example, UCYN-A's niches are distinct from other diazotrophs: high $\mathrm{N}_{2}$ fixation rates and UCYN-A abundance were unexpectedly observed in cold and nitrogen-present regions, challenging traditional assumptions and models about favorable conditions to diazotrophy. Therefore, modeling of $\mathrm{N}_{2}$ fixation ultimately requires observation and simulation of more diverse diazotrophic groups in addition to well-recognized Trichodesmium. Furthermore, deeper investigation of factors unobserved in this study, which may play important roles, such as top-down controls upon $\mathrm{N}_{2}$ fixation [12], would represent valuable avenues for future research. Nevertheless, our approaches for studying the ecophysiology of diverse diazotrophs and for conducting large-scale, high-resolution surveys over broad ocean regimes offer considerable potential for improving our understanding of $\mathrm{N}_{2}$ fixation and our ability to simulate $\mathrm{N}_{2}$ fixation in a changing climate.

Acknowledgements We thank the marine technicians and crew of the $R / V$ Atlantic Explorer for their invaluable help during the cruise. We appreciate discussions with M. Susan Lozier (Duke University) on the analysis of physical supply of phosphorus. We would also like to thank NASA and NOAA for processing and distributing the Ocean Color, and World Ocean Atlas and ETOPO1 bathymetry data, respectively. This study has been conducted using E.U. Copernicus Marine Service Information (geostrophic velocity). WT would like to thank Yajuan Lin
(Duke University) for suggestions on the analysis of nifH sequences. WT's visit to National Oceanography Centre (Southampton) was funded by the Duke Graduate School and Duke Interdisciplinary Studies through The Dissertation Research Travel Award: International and the Graduate Student Training Enhancement Grant (GSTEG), respectively. NC, WT, and SW were supported by the NSF-CAREER grant (\#1350710). NC, HP and HW were also funded by the "Laboratoire d'Excellence" LabexMER (ANR-10-LABX-19) and co-funded by a grant from the French government under the program "Investissements d'Avenir". JR, MM and RoCSI development costs were supported by NERC grant NE/N006496/1 and AtlantOS (Horizon 2020).

\section{Compliance with ethical standards}

Conflict of interest The authors declare that they have no conflict of interest.

Publisher's note Springer Nature remains neutral with regard to jurisdictional claims in published maps and institutional affiliations.

\section{References}

1. Gruber N, Galloway JN. An Earth-system perspective of the global nitrogen cycle. Nature. 2008;451:293-6.

2. Sohm JA, Webb EA, Capone DG. Emerging patterns of marine nitrogen fixation. Nat Rev Microbiol. 2011;9:499-508.

3. Karl D, Letelier R, Tupas L, Dore J, Christian J, Hebel D. The role of nitrogen fixation in biogeochemical cycling in the subtropical North Pacific Ocean. Nature. 1997;388:533-8.

4. Ko YH, Lee K, Takahashi T, Karl DM, Kang S-H, Lee E. Carbonbased estimate of nitrogen fixation-derived net community production in N-depleted ocean gyres. Glob Biogeochem Cycles. 2018;32:1241-52.

5. Deutsch C, Sigman DM, Thunell RC, Meckler AN, Haug GH. Isotopic constraints on glacial/interglacial changes in the oceanic nitrogen budget. Glob Biogeochem Cycles. 2004;18:GB4012.

6. Falkowski PG. Evolution of the nitrogen cycle and its influence on the biological sequestration of $\mathrm{CO}_{2}$ in the ocean. Nature. 1997;387:272-5.

7. Michaels AF, Karl DM, Capone DG. Element stoichiometry, new production and nitrogen fixation. Oceanography. 2001;14:68-77.

8. Moisander PH, Beinart RA, Hewson I, White AE, Johnson KS, Carlson CA, et al. Unicellular cyanobacterial distributions broaden the oceanic $\mathrm{N}_{2}$ fixation domain. Science. 2010;327:1512-4.

9. Sañudo-Wilhelmy SA, Kustka AB, Gobler CJ, Hutchins DA, Yang M, Lwiza K, et al. Phosphorus limitation of nitrogen fixation by Trichodesmium in the central Atlantic Ocean. Nature. 2001;411:66-9.

10. Knapp AN, Casciotti KL, Berelson WM, Prokopenko MG, Capone DG. Low rates of nitrogen fixation in eastern tropical South Pacific surface waters. Proc Natl Acad Sci USA. 2016;113: 4398-403.

11. Ward BA, Dutkiewicz S, Moore CM, Follows MJ. Iron, phosphorus, and nitrogen supply ratios define the biogeography of nitrogen fixation. Limnol Oceanogr. 2013;58:2059-75.

12. Wang W-L, Moore JK, Martiny AC, Primeau FW. Convergent estimates of marine nitrogen fixation. Nature. 2019;566:205-11.

13. Weber T, Deutsch C. Local versus basin-scale limitation of marine nitrogen fixation. Proc Natl Acad Sci USA. 2014;111:8741-6.

14. Mills MM, Ridame C, Davey M, La Roche J, Geider RJ. Iron and phosphorus co-limit nitrogen fixation in the eastern tropical North Atlantic. Nature. 2004:429:292-4. 
15. Luo YW, Lima ID, Karl DM, Deutsch CA, Doney SC. Data-based assessment of environmental controls on global marine nitrogen fixation. Biogeosciences. 2014;11:691-708.

16. Moore CM, Mills MM, Achterberg EP, Geider RJ, LaRoche J, Lucas MI, et al. Large-scale distribution of Atlantic nitrogen fixation controlled by iron availability. Nat Geosci. 2009;2: $867-71$.

17. Ratten J-M, LaRoche J, Desai DK, Shelley RU, Landing WM, Boyle E, et al. Sources of iron and phosphate affect the distribution of diazotrophs in the North Atlantic. Deep Sea Res Part II: Topical Stud Oceanogr. 2015;116:332-41.

18. Straub M, Sigman DM, Ren H, Martínez-García A, Meckler AN, Hain MP, et al. Changes in North Atlantic nitrogen fixation controlled by ocean circulation. Nature. 2013;501:200-4.

19. Dugdale R, Menzel DW, Ryther JH. Nitrogen fixation in the Sargasso Sea. Deep Sea Res. 1961;7:297-300.

20. Capone DG, Burns JA, Montoya JP, Subramaniam A, Mahaffey C, Gunderson T, et al. Nitrogen fixation by Trichodesmium spp.: an important source of new nitrogen to the tropical and subtropical North Atlantic Ocean. Glob Biogeochem Cycles. 2005;19:GB2024.

21. Martínez-Pérez C, Mohr W, Löscher CR, Dekaezemacker J, Littmann S, Yilmaz $P$, et al. The small unicellular diazotrophic symbiont, UCYN-A, is a key player in the marine nitrogen cycle. Nat Microbiol. 2016;1:16163.

22. Delmont TO, Quince C, Shaiber A, Esen OC, Lee ST, Rappe MS, et al. Nitrogen-fixing populations of Planctomycetes and Proteobacteria are abundant in surface ocean metagenomes. Nat Microbiol. 2018;3:804-13.

23. Tang W, Wang S, Fonseca-Batista D, Dehairs F, Gifford S, Gonzalez AG, et al. Revisiting the distribution of oceanic $\mathrm{N}_{2}$ fixation and estimating diazotrophic contribution to marine production. Nat Commun. 2019;10:831.

24. Cassar N, Tang W, Gabathuler H, Huang K. Method for high frequency underway $\mathrm{N}_{2}$ fixation measurements: flow-through incubation acetylene reduction assays by cavity ring down laser absorption spectroscopy (FARACAS). Anal Chem. 2018;90:2839-51.

25. Bruland KW, Rue EL, Smith GJ, DiTullio GR. Iron, macronutrients and diatom blooms in the Peru upwelling regime: brown and blue waters of Peru. Mar Chem. 2005;93:81-103.

26. Raimbault P, Slawyk G, Coste B, Fry J. Feasibility of using an automated colorimetric procedure for the determination of seawater nitrate in the 0 to $100 \mathrm{nM}$ range: examples from field and culture. Marine Biol. 1990;104:347-51.

27. Strickland JD, Parsons T. A practical handbook of seawater analysis. Ottawa; 1972.

28. Cutter G, Andersson P, Codispoti L, Croot P, Francois R, Lohan $\mathrm{M}$, et al. Sampling and sample-handling protocols for GEOTRACES cruises. GEOTRACES; 2010.

29. Lagerström M, Field M, Séguret M, Fischer L, Hann S, Sherrell R. Automated on-line flow-injection ICP-MS determination of trace metals ( $\mathrm{Mn}, \mathrm{Fe}, \mathrm{Co}, \mathrm{Ni}, \mathrm{Cu}$ and $\mathrm{Zn}$ ) in open ocean seawater: application to the GEOTRACES program. Mar Chem. 2013;155: 71-80.

30. Berthelot H, Benavides M, Moisander PH, Grosso O, Bonnet S. High-nitrogen fixation rates in the particulate and dissolved pools in the Western Tropical Pacific (Solomon and Bismarck Seas). Geophys Res Lett. 2017;44:8414-23.

31. Montoya JP, Voss M, Kahler P, Capone DG. A simple, highprecision, high-sensitivity tracer assay for $\mathrm{N}_{2}$ fixation. Appl Environ Microbiol. 1996;62:986-93.

32. Cassar N, Barnett BA, Bender ML, Kaiser J, Hamme RC, Tilbrook B. Continuous high-frequency dissolved $\mathrm{O}_{2} / \mathrm{Ar}$ measurements by equilibrator inlet mass spectrometry. Anal Chem. 2009;81:1855-64.

33. Craig H, Hayward T. Oxygen supersaturation in the ocean: biological versus physical contributions. Science. 1987;235:199-202.
34. Zehr J, Turner P. Nitrogen fixation: nitrogenase genes and gene expression. Method Microbiol. 2001;30:271-86.

35. Turk KA, Rees AP, Zehr JP, Pereira N, Swift P, Shelley R, et al. Nitrogen fixation and nitrogenase (nifH) expression in tropical waters of the eastern North Atlantic. ISME J 2011;5:1201-12.

36. Caporaso JG, Kuczynski J, Stombaugh J, Bittinger K, Bushman FD, Costello EK, et al. QIIME allows analysis of high-throughput community sequencing data. Nat Methods. 2010;7:335-6.

37. Edgar RC. Search and clustering orders of magnitude faster than BLAST. Bioinformatics. 2010;26:2460-1.

38. Edgar RC. UPARSE: highly accurate OTU sequences from microbial amplicon reads. Nature Methods. 2013;10:996.

39. Church MJ, Jenkins BD, Karl DM, Zehr JP. Vertical distributions of nitrogen-fixing phylotypes at Stn ALOHA in the oligotrophic North Pacific Ocean. Aquat Microbial Ecol. 2005;38:3-14.

40. Robidart JC, Church MJ, Ryan JP, Ascani F, Wilson ST, Bombar D, et al. Ecogenomic sensor reveals controls on $\mathrm{N}_{2}$-fixing microorganisms in the North Pacific Ocean. The. ISME J. 2014;8:1175-85.

41. Sipler RE, Gong D, Baer SE, Sanderson MP, Roberts QN, Mulholland MR, et al. Preliminary estimates of the contribution of Arctic nitrogen fixation to the global nitrogen budget. Limnol Oceanogr Lett. 2017;2:159-66.

42. Shiozaki T, Fujiwara A, Ijichi M, Harada N, Nishino S, Nishi S, et al. Diazotroph community structure and the role of nitrogen fixation in the nitrogen cycle in the Chukchi Sea (western Arctic Ocean). Limnol Oceanogr. 2018;63:2191-205.

43. Needoba JA, Foster RA, Sakamoto C, Zehr JP, Johnson KS. Nitrogen fixation by unicellular diazotrophic cyanobacteria in the temperate oligotrophic North Pacific Ocean. Limnol Oceanogr. 2007;52:1317-27.

44. Mulholland MR, Bernhardt PW, Widner BN, Selden CR, Chappell $\mathrm{PD}$, Clayton $\mathrm{S}$, et al. High rates of $\mathrm{N}_{2}$ fixation in temperate, Western North Atlantic coastal waters expand the realm of marine diazotrophy. Glob Biogeochem Cycles. 2019;32:826-40.

45. Benavides M, Voss M. Five decades of $\mathrm{N}_{2}$ fixation research in the North Atlantic Ocean. Front Mar Sci. 2015;2:40.

46. Townsend DW. Sources and cycling of nitrogen in the Gulf of Maine. J Mar Syst. 1998;16:283-95.

47. Fennel K, Wilkin J, Levin J, Moisan J, O'Reilly J, Haidvogel D. Nitrogen cycling in the Middle Atlantic Bight: results from a three-dimensional model and implications for the North Atlantic nitrogen budget. Glob Biogeochem Cycles. 2006;20:GB3007.

48. Fuglister FC, Voorhis AD. A new method of tracking the Gulf Stream 1. Limnol Oceanogr. 1965;10:R115-24.

49. Luo YW, Doney SC, Anderson LA, Benavides M, Berman-Frank I, Bode A, et al. Database of diazotrophs in global ocean: abundance, biomass and nitrogen fixation rates. Earth System Science. Data. 2012;4:47-73.

50. Bonnet S, Caffin M, Berthelot $\mathrm{H}$, Moutin T. Hot spot of $\mathrm{N}_{2}$ fixation in the western tropical South Pacific pleads for a spatial decoupling between $\mathrm{N}_{2}$ fixation and denitrification. Proc Natl Acad Sci USA. 2017;114:2800-1.

51. Ahmed A, Gauns M, Kurian S, Bardhan P, Pratihary A, Naik H, et al. Nitrogen fixation rates in the eastern Arabian Sea. Estuar Coas Shelf Sci. 2017;191:74-83.

52. Gandhi N, Singh A, Prakash S, Ramesh R, Raman M, Sheshshayee $\mathrm{M}$, et al. First direct measurements of $\mathrm{N}_{2}$ fixation during a Trichodesmium bloom in the eastern Arabian Sea. Glob Biogeochem Cycles. 2011;25:GB4014.

53. Xu Y, Chant R, Gong D, Castelao R, Glenn S, Schofield O. Seasonal variability of chlorophyll a in the Mid-Atlantic Bight. Cont Shelf Res. 2011;31:1640-50.

54. Moline MA, Frazer TK, Chant R, Glenn S, Jacoby CA, Reinfelder JR, et al. Biological responses in a dynamic buoyant river plume. Oceanography. 2008;21:70-89. 
55. Zehr JP, Mellon MT, Zani S. New nitrogen-fixing microorganisms detected in oligotrophic oceans by amplification of nitrogenase (nifH) genes. Appl Environ Microbiol. 1998;64:3444-50.

56. Langlois RJ, Hümmer D, LaRoche J. Abundances and distributions of the dominant nifH phylotypes in the Northern Atlantic Ocean. Appl Environ Microbiol. 2008;74:1922-31.

57. Benavides M, Moisander PH, Daley MC, Bode A, Arístegui J. Longitudinal variability of diazotroph abundances in the subtropical North Atlantic Ocean. J Plankton Res. 2016;38: 662-72.

58. Stenegren M, Caputo A, Berg C, Bonnet S, Foster RA. Distribution and drivers of symbiotic and free-living diazotrophic cyanobacteria in the western tropical South Pacific. Biogeosciences. 2018;15:1559-78.

59. Chen M, Lu Y, Jiao N, Tian J, Kao S-J, Zhang Y. Biogeographic drivers of diazotrophs in the western Pacific Ocean. Limnol Oceanogr. 2019;64:1403-21.

60. He R, Chen K, Fennel K, Gawarkiewicz GG, McGillicuddy DJ Jr. Seasonal and interannual variability of physical and biological dynamics at the shelfbreak front of the Middle Atlantic Bight: nutrient supply mechanisms. Biogeosciences. 2011;8: 2935-46.

61. Nixon SW, Ammerman JW, Atkinson LP, Berounsky VM, Billen $\mathrm{G}$, Boicourt WC, et al. The fate of nitrogen and phosphorus at the land-sea margin of the North Atlantic Ocean. Biogeochemistry. 1996;35:141-80.

62. Wu J, Sunda W, Boyle EA, Karl DM. Phosphate depletion in the western North Atlantic Ocean. Science. 2000;289:759-62.

63. Coles V, Hood R. Modeling the impact of iron and phosphorus limitations on nitrogen fixation in the Atlantic Ocean. Biogeosciences. 2007;4:455-79.

64. Palter JB, Lozier MS, Sarmiento JL, Williams RG. The supply of excess phosphate across the Gulf Stream and the maintenance of subtropical nitrogen fixation. Glob Biogeochem Cycles. 2011;25: GB4007.

65. Rijkenberg MJ, Middag R, Laan P, Gerringa LJ, van Aken HM, Schoemann V, et al. The distribution of dissolved iron in the West Atlantic Ocean. PLoS ONE. 2014;9:e101323.

66. Boatman TG, Oxborough K, Gledhill M, Lawson T, Geider RJ. An integrated response of Trichodesmium erythraeum IMS101 growth and photo-physiology to iron, $\mathrm{CO}_{2}$, and light intensity. Front Microbiol. 2018;9:624.

67. Parekh P, Follows MJ, Boyle EA. Decoupling of iron and phosphate in the global ocean. Glob Biogeochem Cycles. 2005;19: GB2020.

68. Sedwick P, Bernhardt P, Mulholland M, Najjar R, Blumen L, Sohst $\mathrm{B}$, et al. Assessing phytoplankton nutritional status and potential impact of wet deposition in seasonally oligotrophic waters of the Mid-Atlantic Bight. Geophys Res Lett. 2018;45:3203-11.

69. Kustka A, Sañudo-Wilhelmy S, Carpenter EJ, Capone DG, Raven JA. A revised estimate of the iron use efficiency of nitrogen fixation, with special reference to the marine cyanobacterium Trichodesmium spp.(Cyanophyta) ${ }^{1}$. J Phycol. 2003;39:12-25.

70. Buck KN, Sohst B, Sedwick PN. The organic complexation of dissolved iron along the U.S. GEOTRACES (GA03) North Atlantic Section. Deep Sea Res Part II: Top Stud Oceanogr. 2015;116:152-65.

71. Lopez JS, Lee L, Mackey KRM. The toxicity of copper to Crocosphaera watsonii and other marine phytoplankton: a systematic review. Front Mar Sci. 2019;5:511.

72. Boyle EA, Huested SS, Jones SP. On the distribution of copper, nickel, and cadmium in the surface waters of the North Atlantic and North Pacific Ocean. J Geophys Res. 1981;86(C9): 8048-66.
73. Roshan $\mathrm{S}, \mathrm{Wu}$ J. The distribution of dissolved copper in the tropical-subtropical north Atlantic across the GEOTRACES GA03 transect. Mar Chem. 2015;176:189-98.

74. Semeniuk DM, Taylor RL, Bundy RM, Johnson WK, Cullen JT, Robert M, et al. Iron-copper interactions in iron-limited phytoplankton in the northeast subarctic Pacific Ocean. Limnol Oceanogr. 2016;61:279-97.

75. Moffett JW, Tuit CB, Ward BB. Chelator-induced inhibition of copper metalloenzymes in denitrifying bacteria. Limnol Oceanogr. 2012;57:272-80.

76. Tucker DL, Hirsh K, Li H, Boardman B, Sherman LA. The manganese stabilizing protein (MSP) and the control of $\mathrm{O}_{2}$ evolution in the unicellular, diazotrophic cyanobacterium, Cyanothece sp. ATCC 51142. Biochim Biophys Acta. 2001;1504:409-22.

77. Hood G, Ramachandran V, East AK, Downie JA, Poole PS. Manganese transport is essential for $\mathrm{N}_{2}$-fixation by Rhizobium leguminosarum in bacteroids from galegoid but not phaseoloid nodules. Environ Microbiol. 2017;19:2715-26.

78. Hulten Mv, Middag R, Dutay J-C, Baar Hd, Roy-Barman M, Gehlen M, et al. Manganese in the west Atlantic Ocean in the context of the first global ocean circulation model of manganese. Biogeosciences. 2017;14:1123-52.

79. Paytan A, McLaughlin K. The oceanic phosphorus cycle. Chem Rev. 2007;107:563-76.

80. Fonseca-Batista D, Li X, Riou V, Michotey V, Deman F, Fripiat $\mathrm{F}$, et al. Evidence of high $\mathrm{N}_{2}$ fixation rates in the temperate northeast Atlantic. Biogeosciences. 2019;16:999-1017.

81. Breitbarth E, Oschlies A, LaRoche J. Physiological constraints on the global distribution of Trichodesmium - effects of temperature on diazotrophy. Biogeosciences. 2007;4:53-61.

82. Sohm JA, Capone DG. Phosphorus dynamics of the tropical and subtropical north Atlantic: Trichodesmium spp. versus bulk plankton. Mar Ecol Prog Ser. 2006;317:21-8.

83. Lipschultz F, Owens NJ. An assessment of nitrogen fixation as a source of nitrogen to the North Atlantic Ocean. Biogeochemistry. 1996;35:261-74.

84. Rivero-Calle S, Del Castillo CE, Gnanadesikan A, Dezfuli A, Zaitchik B, Johns DG. Interdecadal Trichodesmium variability in cold North Atlantic waters. Glob Biogeochem Cycles. 2016;30:1620-38.

85. Rees AP, Tait K, Widdicombe CE, Quartly GD, McEvoy AJ, AlMoosawi L. Metabolically active, non-nitrogen fixing, Trichodesmium in UK coastal waters during winter. J Plankton Res. 2016;38:673-8.

86. Pelegrí J, Csanady G. Nutrient transport and mixing in the Gulf Stream. J Geophys Res. 1991;96(C2):2577-83.

87. Shiozaki T, Takeda S, Itoh S, Kodama T, Liu X, Hashihama F, et al. Why is Trichodesmium abundant in the Kuroshio? Biogeosciences. 2015;12:6931-43.

88. Needham DM, Fichot EB, Wang E, Berdjeb L, Cram JA, Fichot CG, et al. Dynamics and interactions of highly resolved marine plankton via automated high-frequency sampling. ISME J. 2018;12: 2417-32.

89. Gérikas Ribeiro C, Lopes dos Santos A, Marie D, Pereira Brandini F, Vaulot D. Small eukaryotic phytoplankton communities in tropical waters off Brazil are dominated by symbioses between Haptophyta and nitrogen-fixing cyanobacteria. ISME J. 2018;12: 1360-74.

90. Harding K, Turk-Kubo KA, Sipler RE, Mills MM, Bronk DA, Zehr JP. Symbiotic unicellular cyanobacteria fix nitrogen in the Arctic Ocean. Proc Natl Acad Sci USA. 2018;115:13371-5.

91. Collos Y, Vaquer A, Souchu P. Acclimation of nitrate uptake by phytoplankton to high substrate levels1. J Phycol. 2005;41: 466-78. 
92. Harrison WG, Harris LR, Irwin BD. The kinetics of nitrogen utilization in the oceanic mixed layer: Nitrate and ammonium interactions at nanomolar concentrations. Limnol Oceanogr. 1996;41:16-32.

93. Bombar D, Paerl RW, Riemann L. Marine non-cyanobacterial diazotrophs: moving beyond molecular detection. Trends in Microbiol. 2016;24:916-27.

94. Knapp AN. The sensitivity of marine $\mathrm{N}_{2}$ fixation to dissolved inorganic nitrogen. Front Microbiol. 2012;3.

95. Großkopf T, LaRoche J. Direct and indirect costs of dinitrogen fixation in Crocosphaera watsonii WH8501 and possible implications for the nitrogen cycle. Front Microbiol. 2012;3:236.
96. Krupke A, Mohr W, LaRoche J, Fuchs BM, Amann RI, Kuypers MM. The effect of nutrients on carbon and nitrogen fixation by the UCYN-A-haptophyte symbiosis. ISME J. 2015;9:1635-47.

97. Martiny AC, Coleman ML, Chisholm SW. Phosphate acquisition genes in Prochlorococcus ecotypes: Evidence for genome-wide adaptation. Proc Natl Acad Sci USA. 2006;103: 12552-7.

98. Rouco M, Frischkorn KR, Haley ST, Alexander H, Dyhrman ST. Transcriptional patterns identify resource controls on the diazotroph Trichodesmium in the Atlantic and Pacific oceans. ISME J. 2018;12:1486-95. 